\title{
Zirconium-Catalyzed Alkene Hydrophosphination and Dehydrocoupling with an Air-Stable, Fluorescent Primary Phosphine
}

\author{
Christine A. Bange ${ }^{1}$, Neil T. Mucha ${ }^{1,+}$, Morgan E. Cousins ${ }^{1}$, Abigail C. Gehsmann ${ }^{1}$, \\ Anna Singer ${ }^{1}$, Taylor Truax ${ }^{1}$, Lee J. Higham ${ }^{2, *}$ and Rory Waterman ${ }^{1, *}$ \\ 1 Department of Chemistry, University of Vermont, 82 University Place, Burlington, VT 05401, USA; \\ Christine.Bange@uvm.edu (C.A.B.); ntm50014@gmail.com (N.T.M.); Morgan.Cousins@uvm.edu (M.E.C.); \\ agehsmann@ccsuvt.org (A.C.G.); asinger@ccsuvt.org (A.S.); ttruax@ccsuvt.org (T.T.) \\ 2 School of Chemistry, Newcastle University, Newcastle upon Tyne NE1 7RU, UK \\ * Correspondence: lee.higham@ncl.ac.uk (L.J.H.); rory.waterman@uvm.edu (R.W.); \\ Tel.: +44-191-208-5542 (L.J.H.); +1-802-656-0278 (R.W.) \\ † Current address: Brandeis University, 415 South Street, MS015, Waltham, MA 02453, USA \\ Academic Editor: J. Derek Woollins \\ Received: 22 July 2016; Accepted: 8 August 2016; Published: 15 August 2016
}

\begin{abstract}
Zirconium-catalyzed alkene hydrophosphination and dehydrocoupling with an air-stable, fluorescent primary phosphine 8-[(4-phosphino)phenyl]-4,4-dimethyl-1,3,5,7-tetramethyl-2,6-diethyl4-bora-3a,4a-diaza-s-indacene furnishes fluorescent phosphine products. Hydrophosphination of the fluorescent phosphine produces products with a complete selectivity for the secondary product. A key intermediate in catalysis, a zirconium phosphido compound, was isolated.
\end{abstract}

Keywords: hydrophosphination; dehydrocoupling; primary phosphines; fluorescence

\section{Introduction}

Construction of P-E bonds to form novel organophosphines is of intense, ongoing interest [1]. The goal of $\mathrm{P}-\mathrm{E}$ bond formation in a selective, atom-economical, and efficient manner has motivated efforts in two principal catalytic approaches: hydrophosphination to make P-C bonds [2] and dehydrocoupling to make P-P bonds [3]. Pursuant to both approaches, we have demonstrated hydrophosphination [4-6] and dehydrocoupling [7-9] of primary phosphine substrates with [ $\left.\kappa^{5}-\mathrm{N}, \mathrm{N}, \mathrm{N}, \mathrm{N}, \mathrm{C}-\left(\mathrm{Me}_{3} \mathrm{SiNCH}_{2} \mathrm{CH}_{2}\right)_{2} \mathrm{NCH}_{2} \mathrm{CH}_{2} \mathrm{NSiMe}_{2} \mathrm{CH}\right] \mathrm{Zr}$ (1) [8] (Scheme 1) where phosphide compounds (i.e., $\left(\mathrm{N}_{3} \mathrm{~N}\right) \mathrm{ZrPHR} ; \mathrm{N}_{3} \mathrm{~N}=\mathrm{N}\left(\mathrm{CH}_{2} \mathrm{CH}_{2} \mathrm{NSiMe}_{3}\right)_{3}{ }^{3-}$ ) are key intermediates.

Catalytic hydrophosphination has yielded advances in selective $\mathrm{P}-\mathrm{C}$ bond formation, but phosphine substrates are largely limited to secondary derivatives. Over the past two years, primary phosphines have emerged significantly, but these substrates are still underrepresented despite the potential for further functionalization of the products $[2,10,11]$. Even in those examples, the primary phosphines substrate is often sterically unencumbered, such as $\mathrm{PhPH}_{2}$, but it is sterically demanding phosphines that are of interest. Therefore, expansion of the phosphine substrates that engage in P-E bond formation, such as hydrophosphination, is of significant interest. 


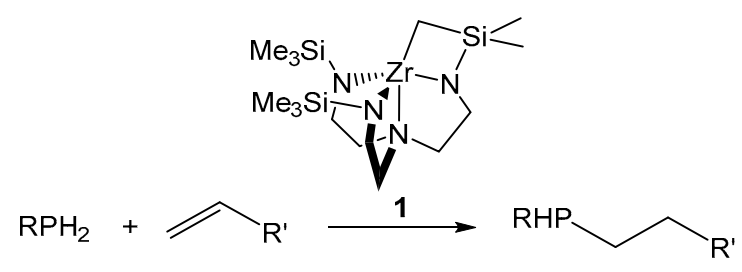

hydrophosphination

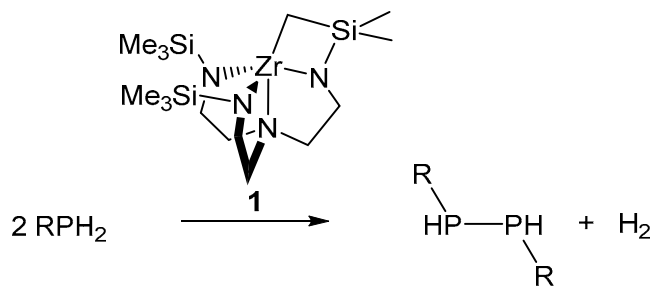

dehydrocoupling

Scheme 1. Zirconium-catalyzed hydrophosphination and dehydrocoupling of primary phosphines.

Primary phosphines can be difficult to handle due to toxicity and facile oxidation that renders many simple derivatives pyrophoric. A vigorous effort to understand and expend the family of air-stable primary phosphines emerged in recent years to avail greater use of these molecules [12-15]. Among this class of primary phosphines are 8-[(4-phosphino)phenyl]4,4-dimethyl-1,3,5,7-tetramethyl-2,6-diethyl-4-bora-3a,4a-diaza-s-indacene (2) [12,15-18] and (2'-methoxy[1,1'-binaphthalen]-2-yl)phosphine (3) [19,20] (Figure 1). Preliminary reactivity studies of 2 indicate that the air stability does not impact the reactivity at phosphorus.

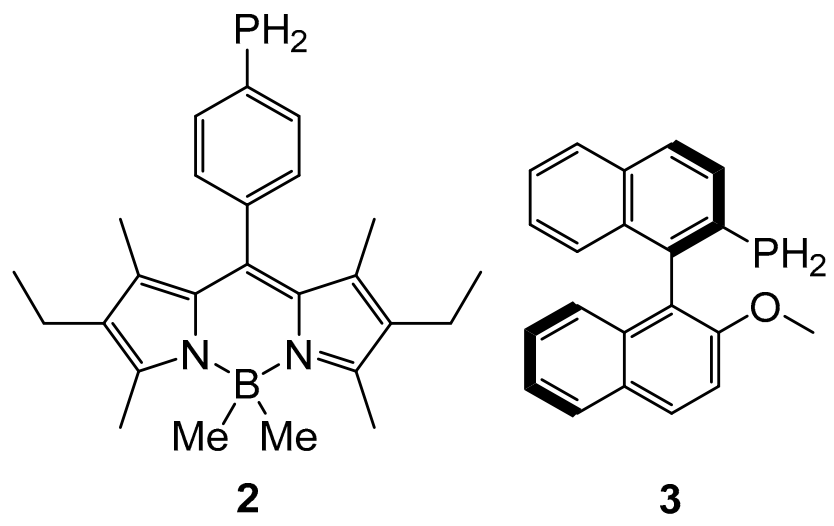

Figure 1. Examples of air-stable primary phosphines.

\section{Results and Discussion}

Previously, hydrophosphination of alkenes and imines substrates with $\mathbf{3}$ was shown to provide selective formation of secondary phosphines with exclusive anti-Markovnikov formation (Scheme 2) [6]. Despite the size of the binaphthyl backbone, catalytic hydrophosphination with 3 readily reacts with $\mathbf{1}$ to furnish hydrophosphination products as either secondary phosphines or tertiary phosphines, depending on reaction conditions. Expansion of this catalysis and dehydrocoupling to the fluorescent phosphine $\mathbf{2}$ as a substrate was targeted to further probe air-stable primary phosphine reactivity and support the emergent applications of $\mathbf{2}$ and related compounds [21,22]. Compound $\mathbf{2}$ is of interest and investigation as an imaging probe. 


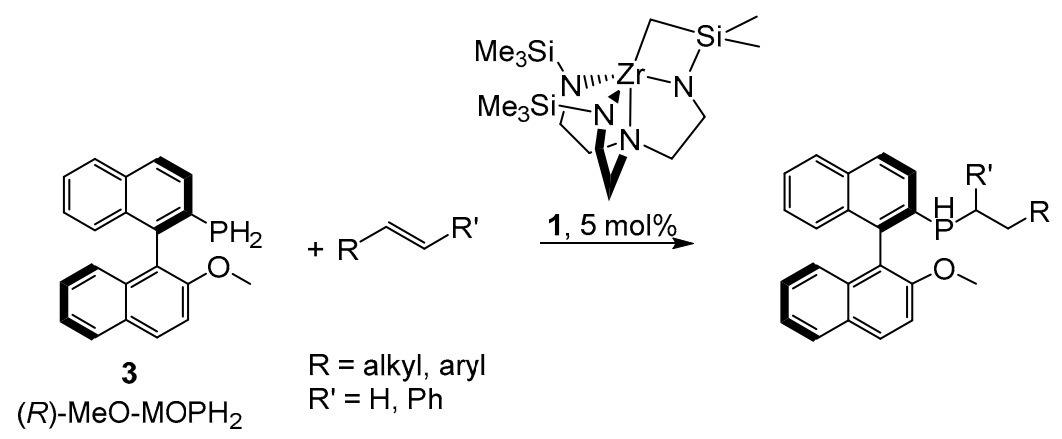

Previous work
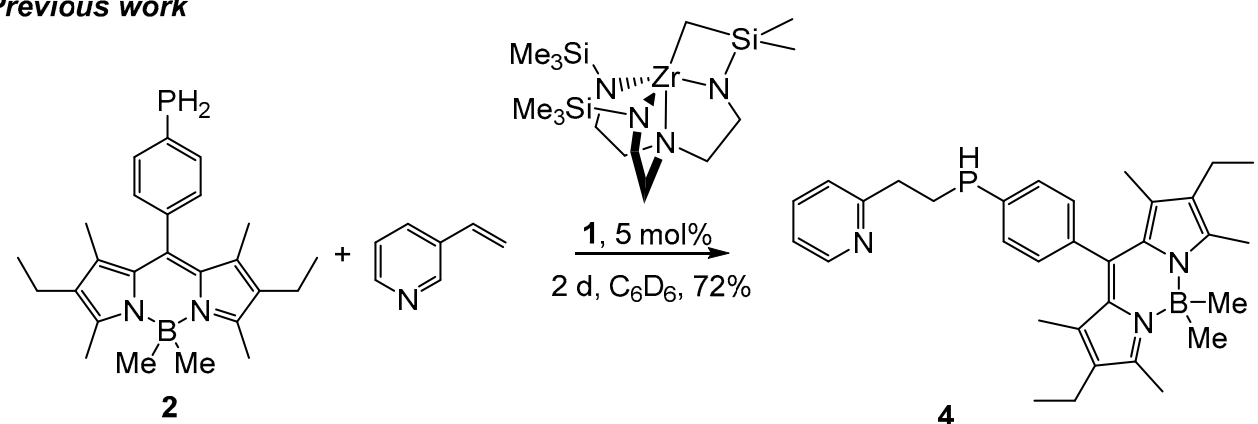

This work

Scheme 2. Catalytic hydrophosphination of air-stable primary phosphines using $\mathbf{1}$.

As anticipated, reaction of 2-vinylpyridine with $\mathbf{2}$ in the presence of $\mathbf{1}$ furnishes the secondary phosphine product with complete anti-Markovnikov selectivity (Scheme 2). This newly-formed hydrophosphination product, 4, displays a single ${ }^{31} \mathrm{P}$ NMR resonance of $\delta=-52.2$ and a P-H resonance of $\delta=3.89$ with $J_{\mathrm{PH}}=199 \mathrm{~Hz}$ indicating a secondary phosphine (Figures S1 and S2). No formation of tertiary phosphine products were detected under these conditions by NMR or mass spectrometry, but it is anticipated that the tertiary phosphines would be available by slight modification of the reaction conditions, as was reported for both $\mathrm{PhPH}_{2}$ [4] and 3 [6].

Treatment of 2 with $5 \mathrm{~mol} \%$ of $\mathbf{1}$ in a vacuum atmosphere results in 39\% conversion to the dehydrocoupled product 5 after $24 \mathrm{~h}$ at $80{ }^{\circ} \mathrm{C}$ (Equation (1)) (Figures S4 and S5).

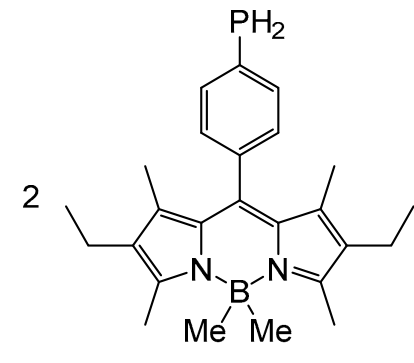

2

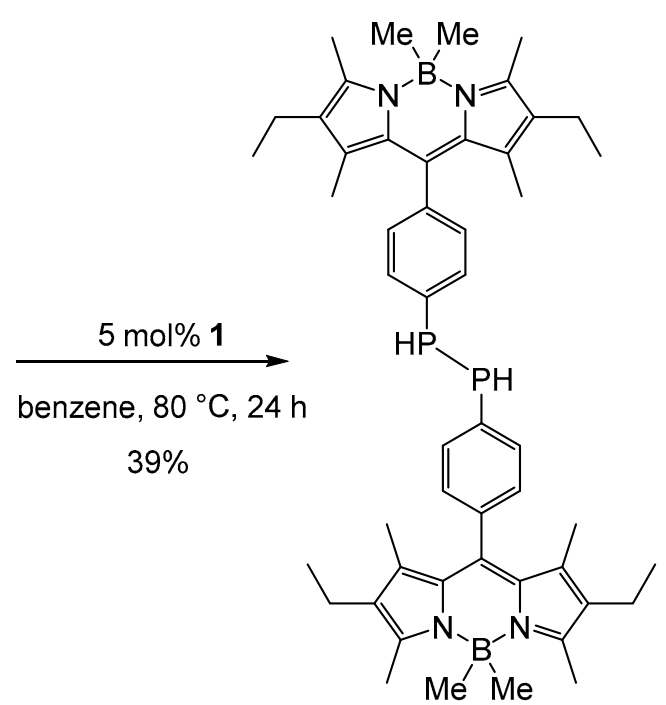

5 
This diphosphine displays resonances in the ${ }^{31} \mathrm{P}$ NMR spectrum at $\delta=-70.8$ and -71.3 corresponding to rac and meso isomers of the diphosphine product, similar to known compounds of this type [3]. The $\mathrm{P}-\mathrm{H}$ protons of 5 resonate at $\delta=3.89\left(\mathrm{JPH}_{\mathrm{PH}}=199 \mathrm{~Hz}\right)$, which is similar to other aryl-substituted secondary diphosphines (e.g., $\left.(p-\mathrm{TolPH})_{2}, \delta=3.99\left(\mathrm{JPH}_{\mathrm{PH}}=198 \mathrm{~Hz}\right)\right)$ [8]. Diphosphines of the type $(\mathrm{RPH})_{2}$, like 5 , are known in some instances to thermally degrade to primary phosphines $\mathrm{RPH}_{2}$ and phosphacycles [23,24], but such products were not observed under these conditions. Phosphine product 5 was not observed as a side product in the hydrophosphination of 2-vinyl pyridine (Scheme 2).

As expected both products retain their fluorescence. Products 4 and 5 were excited at $485 \mathrm{~nm}$ and displayed a maximum emission at 529 and $534 \mathrm{~nm}$, respectively, similar to their precursor 2 (Figures S3 and S6) [14].

The pivotal intermediate in this catalysis is most likely a terminal phosphido complex, and an effort was made to isolate this compound. Treatment of equimolar amounts of $\mathbf{2}$ and $\mathbf{1}$ in toluene results in the formation of the zirconium phosphide $\mathbf{6}$ after ten minutes (Equation (2)). Compound $\mathbf{6}$ was isolated as crimson-colored crystals in $45 \%$ yield by crystallization from a concentrated hexanes solution cooled to $-30{ }^{\circ} \mathrm{C}$ (Figures S7 and S8).
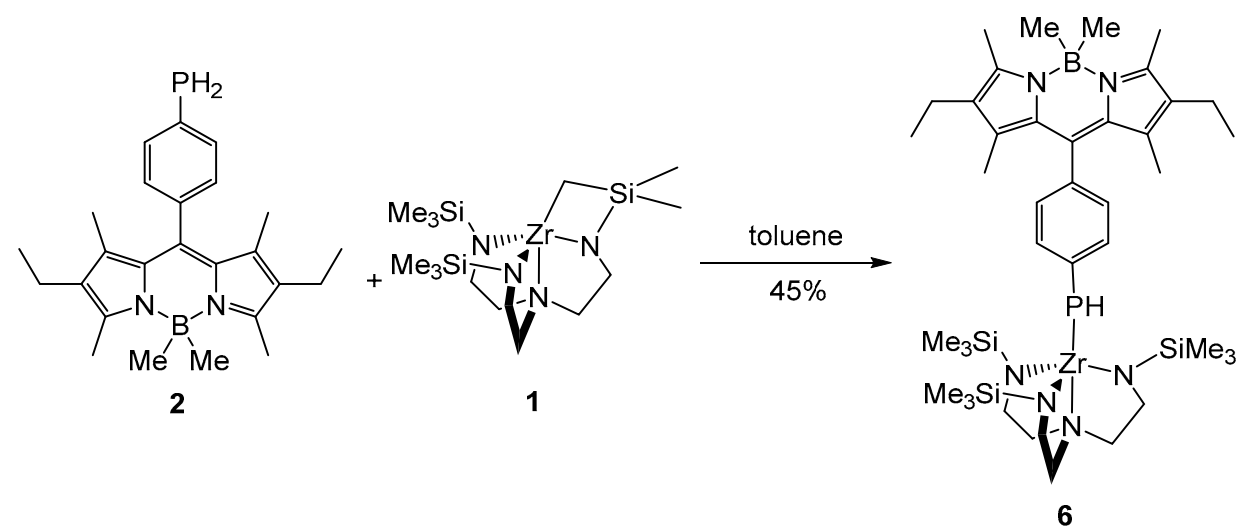

Compound 6 displays a highly symmetric pattern in the ${ }^{1} \mathrm{H}$ NMR spectrum and a dramatic shift in the ${ }^{31} \mathrm{P}$ NMR resonance as compared to phosphine 2 , from $\delta=-124.2$ to $\delta=-43.5$ for $\boldsymbol{6}$. The phosphido proton resonates at $\delta=4.08(\mathrm{JH}=211 \mathrm{~Hz})$ in the ${ }^{1} \mathrm{H} N M R$ spectrum, confirming a secondary phosphine. This complex is highly related to a class of zirconium phosphido complexes formed by insertion of a primary phosphine into $\mathbf{1}[5,6,8,25,26]$ (Figure S9).

\section{Materials and Methods}

All air-sensitive manipulations were performed under a positive pressure of nitrogen using standard Schlenk techniques or in an M. Braun glovebox. Benzene- $d_{6}$ was degassed and dried over $\mathrm{NaK}$ alloy. Starting materials $\left[\kappa^{5}-\mathrm{N}, \mathrm{N}, \mathrm{N}, \mathrm{N}, \mathrm{C}-\left(\mathrm{Me}_{3} \mathrm{SiNCH}_{2} \mathrm{CH}_{2}\right)_{2} \mathrm{NCH}_{2} \mathrm{CH}_{2} \mathrm{NSiMe}_{2} \mathrm{CH}\right] \mathrm{Zr}$ (1) [8] and 8-[(4-phosphino)phenyl]-4,4-dimethyl-1,3,5,7-tetramethyl-2,6-diethyl-4-bora-3a,4a-diaza-s-indacene (2) [16] were prepared according to literature procedures. All other chemicals were obtained from either Alfa Aesar (Ward Hill, MA, USA) or Sigma-Aldrich (St. Louis, MO, USA) and dried by appropriate means. NMR spectra were collected on a Bruker AXR $500 \mathrm{MHz}$ spectrometer (Bruker, Billerica, MA, USA) in benzene- $d_{6}$ solution and are reported with reference to residual solvent signals (e.g., benzene- $d_{6}, \delta 7.16$ and 128.0 ) or to an external standard of $85 \% \mathrm{H}_{3} \mathrm{PO}_{4}(\delta 0.0)$ for ${ }^{31} \mathrm{P} \mathrm{NMR}$ spectra. Conversions are determined by integration of the ${ }^{31} \mathrm{P}\left\{{ }^{1} \mathrm{H}\right\} \mathrm{NMR}$ spectra. Pulse sequences for ${ }^{31} \mathrm{P}$ NMR spectra that are suitable for integration have been reported [4]. Absorption spectra were recorded with a QuantaMaster 4 fluorescence spectrophotometer (PTI, Edison, NJ, USA) as THF solutions. Samples were excited at $485 \mathrm{~nm}$ with excitation and emission slits each set to $1 \mathrm{~nm}$. IR data were collected on a Shimazdu IRAffinity-1 FTIR spectrometer (Shimadzu, Kyoto, Japan). 
For catalytic hydrophosphination to form 4, a J-Young type NMR tube was charged with $16.1 \mathrm{mg}$ $(0.040 \mathrm{mmol})$ of $\mathbf{2}, 4.2 \mathrm{mg}(0.040 \mathrm{mmol})$ of 2-vinyl pyridine, $0.9 \mathrm{mg}$ of $\mathbf{1}(0.002 \mathrm{mmol})$, and those reagents were dissolved in benzene- $d_{6}$. The NMR tube was capped and heated to $80{ }^{\circ} \mathrm{C}$ in a silicon oil bath for two days to achieve $72 \%$ NMR conversion to 4 .

For catalytic dehydrocoupling to form 5, a J-Young type NMR tube was charged with $23.9 \mathrm{mg}$ $(0.059 \mathrm{mmol})$ of $\mathbf{2}, 1.3 \mathrm{mg}$ of $\mathbf{1}(0.003 \mathrm{mmol})$, and those reagents were dissolved in benzene- $d_{6}$. The solution was frozen, the headspace was evacuated, and the reaction was heated to $80{ }^{\circ} \mathrm{C}$ in a silicon oil bath for $24 \mathrm{~h}$ to achieve $39 \%$ conversion to the diphosphine, $\mathbf{5}$, according to integration of the ${ }^{31} \mathrm{P}$ NMR spectrum.

For formation of $\mathbf{6}$, a scintillation vial was charged with $8.8 \mathrm{mg}(0.022 \mathrm{mmol})$ of $\mathbf{2}, 10.0 \mathrm{mg}$ of 1 $(0.022 \mathrm{mmol})$, and those solids were dissolved in toluene. The contents were stirred for $10 \mathrm{~min}$, and the toluene was removed under reduced pressure. The crude zirconium phosphide was redissolved in hexanes and cooled to $-30{ }^{\circ} \mathrm{C}$ for four days until crystallization to provide 6 in $45 \%$ yield.

\section{Conclusions}

In summary, the fluorescent primary phosphine 8-[(4-phosphino)phenyl]-4,4-dimethyl-1,3,5,7tetramethyl-2,6-diethyl-4-bora-3a,4a-diaza-s-indacene (2) readily engages in $\mathrm{P}-\mathrm{P}$ and $\mathrm{P}-\mathrm{C}$ bond formation via catalytic dehydrocoupling and hydrophosphination. Catalytic hydrophosphination with 1 selects for formation of the anti-Markovnikov secondary phosphine hydrophosphination product with no detectable formation of tertiary or Marknonikov addition products. Insertion of 2 into the zirconium pre-catalyst 1 results in the formation of the zirconium phosphido complex 6, which is highly related to a broader family of zirconium phosphide complexes.

Supplementary Materials: The following are available online at www.mdpi.com/2304-6740/4/3/26/s1. Figure S1: ${ }^{1} \mathrm{H}$ NMR spectrum of 4; Figure S2: ${ }^{31} \mathrm{P}\left\{{ }^{1} \mathrm{H}\right\}$ NMR spectrum of 4; Figure S3: Fluorescence spectrum of 4; Figure S4: ${ }^{1} \mathrm{H}$ NMR spectrum of 5; Figure S5: ${ }^{31} \mathrm{P}\left\{{ }^{1} \mathrm{H}\right\}$ NMR spectrum of 5. Figure S6: Fluorescence spectrum of 5; Figure S7: ${ }^{1} \mathrm{H}$ NMR spectrum of 6; Figure S8: ${ }^{31} \mathrm{P}\left\{{ }^{1} \mathrm{H}\right\}$ NMR spectrum of 6; Figure S9: IR spectrum of 6.

Acknowledgments: This work was supported by the U.S. National Science Foundation (CHE-1265608 and CHE-1565658 to Rory Waterman) and the EPSRC for a Fellowship (EP/G005206/1 to Lee J. Higham) and for National Mass Spectrometery Service at Swansea. Abigail C. Gehsmann, Anna Singer, and Taylor Truax thank Essex High School for the opportunity to conduct research through the Essex STEM Academy and Women-in-Science programs. The authors thank Willem Leenstra and Matthew D. Liptak for use of their fluorescence spectrophotometer, which is supported by the U.S. National Science Foundation (DMR-1506248 to Matthew D. Liptak).

Author Contributions: Christine A. Bange conducted the experiments, analyzed the data, and wrote the paper, Neil T. Mucha contributed the phosphine 2, Morgan E. Cousins assisted with fluoresce spectroscopy, Abigail C. Gehsmann, Anna Singer, and Taylor Truax assisted in conducting the experiments, Lee J. Higham edited the paper and contributed the phosphine 2, and Rory Waterman edited the paper and designed the experiments. All authors approved the final submission.

Conflicts of Interest: The authors declare no conflict of interest.

\section{References}

1. Gladysz, J.A.; Bedford, R.B.; Fujita, M.; Gabbai, F.P.; Goldberg, K.I.; Holland, P.L.; Kiplinger, J.L.; Krische, M.J.; Louie, J.; Lu, C.C.; et al. Organometallics Roundtable 2013-2014. Organometallics 2014, 33, 1505-1527. [CrossRef]

2. Bange, C.A.; Waterman, R. Challenges in Catalytic Hydrophosphination. Chem. Eur. J. 2016. [CrossRef] [PubMed]

3. Waterman, R. Dehydrogenative bond-forming catalysis involving phosphines. Curr. Org. Chem. 2008, 12, 1322-1339. [CrossRef]

4. Ghebreab, M.B.; Bange, C.A.; Waterman, R. Intermolecular Zirconium-Catalyzed Hydrophosphination of Alkenes and Dienes with Primary Phosphines. J. Am. Chem. Soc. 2014, 136, 9240-9243. [CrossRef] [PubMed] 
5. Roering, A.J.; Leshinski, S.E.; Chan, S.M.; Shalumova, T.; MacMillan, S.N.; Tanski, J.M.; Waterman, R. Insertion Reactions and Catalytic Hydrophosphination by Triamidoamine-Supported Zirconium Complexes. Organometallics 2010, 29, 2557-2565. [CrossRef]

6. Bange, C.A.; Ghebreab, M.B.; Ficks, A.; Mucha, N.T.; Higham, L.; Waterman, R. Zirconium-catalyzed intermolecular hydrophosphination using a chiral, air-stable primary phosphine. Dalton Trans. 2016, 45, 1863-1867. [CrossRef] [PubMed]

7. Roering, A.J.; MacMillan, S.N.; Tanski, J.M.; Waterman, R. Zirconium-Catalyzed Heterodehydrocoupling of Primary Phosphines with Silanes and Germanes. Inorg. Chem. 2007, 46, 6855-6857. [CrossRef] [PubMed]

8. Waterman, R. Selective Dehydrocoupling of Phosphines by Triamidoamine Zirconium Catalysts. Organometallics 2007, 26, 2492-2494. [CrossRef]

9. Ghebreab, M.B.; Shalumova, T.; Tanski, J.M.; Waterman, R. Triamidoamine-supported zirconium complexes in the catalytic dehydrocoupling of 1,2-bisphosphinobenzene and -ethane. Polyhedron 2010, 29, 42-45. [CrossRef]

10. Rosenberg, L. Mechanisms of Metal-Catalyzed Hydrophosphination of Alkenes and Alkynes. ACS Catal. 2013, 3, 2845-2855. [CrossRef]

11. Koshti, V.; Gaikwad, S.; Chikkali, S.H. Contemporary avenues in catalytic PH bond addition reaction: A case study of hydrophosphination. Coord. Chem. Rev. 2014, 265, 52-73. [CrossRef]

12. Davies, L.H.; Stewart, B.; Higham, L.J. Air-stable, fluorescent primary phosphines. Organomet. Chem. 2014, $39,51-71$.

13. Stewart, B.; Harriman, A.; Higham, L.J. Predicting the Air Stability of Phosphines. Organometallics 2011, 30, 5338-5343. [CrossRef]

14. Ficks, A.; Martinez-Botella, I.; Stewart, B.; Harrington, R.W.; Clegg, W.; Higham, L.J. Taming functionality: Easy-to-handle chiral phosphiranes. Chem. Commun. 2011, 47, 8274-8276. [CrossRef] [PubMed]

15. Fleming, J.T.; Higham, L.J. Primary phosphine chemistry. Coord. Chem. Rev. 2015, 297-298, 127-145. [CrossRef]

16. Davies, L.H.; Stewart, B.; Harrington, R.W.; Clegg, W.; Higham, L.J. Air-Stable, Highly Fluorescent Primary Phosphanes. Angew. Chem. Int. Ed. 2012, 51, 4921-4924. [CrossRef] [PubMed]

17. Davies, L.H.; Wallis, J.F.; Probert, M.R.; Higham, L.J. Efficient multigram syntheses of air-stable, fluorescent primary phosphines via palladium-catalyzed phosphonylation of aryl bromides. Synthesis 2014, 46, 2622-2628.

18. Davies, L.H.; Harrington, R.W.; Clegg, W.; Higham, L.J. ${ }^{B} \mathrm{R}_{2} \mathrm{BodPR}_{2}$ : Highly fluorescent alternatives to $\mathrm{PPh}_{3}$ and PhPCy $y_{2}$. Dalton Trans. 2014, 43, 13485-13499. [CrossRef] [PubMed]

19. Ficks, A.; Hiney, R.M.; Harrington, R.W.; Gilheany, D.G.; Higham, L.J. MOP-phosphonites: A novel ligand class for asymmetric catalysis. Dalton Trans. 2012, 41, 3515-3522. [CrossRef] [PubMed]

20. Hiney, R.M.; Ficks, A.; Muller-Bunz, H.; Gilheany, D.G.; Higham, L.J. Air-stable chiral primary phosphines part (I) synthesis, stability and applications. In Organometallic Chemistry; Fairlamb, I.J.S., Lynam, J.M., Eds.; The Royal Society of Chemistry: London, UK, 2011; Volume 37, pp. 27-45.

21. Davies, L.H.; Kasten, B.B.; Benny, P.D.; Arrowsmith, R.L.; Ge, H.; Pascu, S.I.; Botchway, S.W.; Clegg, W.; Harrington, R.W.; Higham, L.J. Re and ${ }^{99} \mathrm{~m}$ Tc complexes of $\mathrm{BodP}_{3}-$ Multi-modality imaging probes. Chem. Commun. 2014, 50, 15503-15505. [CrossRef] [PubMed]

22. Nigam, S.; Burke, B.P.; Davies, L.H.; Domarkas, J.; Wallis, J.F.; Waddell, P.G.; Waby, J.S.; Benoit, D.M.; Seymour, A.-M.; Cawthorne, C.; et al. Structurally optimized BODIPY derivatives for imaging of mitochondrial dysfunction in cancer and heart cells. Chem. Commun. 2016, 52, 7114-7117. [CrossRef] [PubMed]

23. Blaurock, S.; Hey-Hawkins, E. Unexpected reduction of $\left[\mathrm{Cp}^{*} \mathrm{TaCl}_{4}\left(\mathrm{PH}_{2} \mathrm{R}\right)\right](\mathrm{R}=\mathrm{But}, \mathrm{Cy}, \mathrm{Ad}, \mathrm{Ph}$, 2,4,6- $\left.\mathrm{Me}_{3} \mathrm{C}_{6} \mathrm{H}_{2} ; \mathrm{Cp}^{*}=\mathrm{C}_{5} \mathrm{Me}_{5}\right)$ by reaction with DBU-Molecular structure of $[(\mathrm{DBU}) \mathrm{H}]\left[\mathrm{Cp}^{*} \mathrm{TaCl}_{4}\right](\mathrm{DBU}=$ 1,8-diazabicyclo[5.4.0]undec-7-ene). Z. Anorg. Allg. Chem. 2002, 628, 37-40. [CrossRef]

24. Baudler, M.; Gruner, C.; Tschaebunin, H.; Hahn, J. Contributions to the chemistry of phosphorus. 110. 1,2-Di-tert-butyldiphosphine and tert-butyldiphosphine. Chem. Ber. 1982, 115, 1739-1745. [CrossRef] 
25. Roering, A.J.; Maddox, A.F.; Elrod, L.T.; Chan, S.M.; Ghebreab, M.B.; Donovan, K.L.; Davidson, J.J.; Hughes, R.P.; Shalumova, T.; MacMillan, S.N.; et al. General Preparation of $\left(\mathrm{N}_{3} \mathrm{~N}\right) \mathrm{ZrX}\left(\mathrm{N}_{3} \mathrm{~N}=\right.$ $\left.\mathrm{N}\left(\mathrm{CH}_{2} \mathrm{CH}_{2} \mathrm{NSiMe}_{3}\right)_{3}{ }^{3-}\right)$ Complexes from a Hydride Surrogate. Organometallics 2009, 28, 573-581. [CrossRef]

26. Leshinski, S.; Shalumova, T.; Tanski, J.M.; Waterman, R. Insertion reactions involving a triamidoamine-supported zirconium complex. Dalton Trans. 2010, 39, 9073-9078. [CrossRef] [PubMed]

(c) 2016 by the authors; licensee MDPI, Basel, Switzerland. This article is an open access article distributed under the terms and conditions of the Creative Commons Attribution (CC-BY) license (http:/ / creativecommons.org/licenses/by/4.0/). 